\title{
Ultrastruktur Morfologi Polen Arundina graminifolia (D.Don) Hochr. (Orchidaceae)
}

\section{Pollen Morphological Ultrastructure of Arundina graminifolia (D.Don) Hochr. (Orchidaceae)}

Dina Marvianti*), Tesri Maideliza dan Syamsuardi

Herbarium Universitas Andalas, Jurusan Biologi, FMIPA Universitas Andalas, Kampus UNAND Limau Manis Padang 25163

*)Koresponden: dmarvianti@gmail.com

\begin{abstract}
Pollen morphology of three variants of Arundina graminifolia in West Sumatra was examined. The pollen types, shapes, apertures and ornamentations were examined using scanning electron microscope. There was variation of pollen shape between three variant of Arundina graminifolia. There was different of pollen shape white variant to pink and purple variant. The pollen shape of white variant were oblate sferoidal. The prolate shapes were detected at pink and purpe variant. Three variants Arundina graminifolia have the same ornamentation exine that is the reticulum and there kolpus of the same type, namely tri-kolpate and tetra-kolpate
\end{abstract}

Keyword: Arundina graminifolia, pollen morphology

\section{Pendahuluan}

Arundina graminifolia merupakan salah satu jenis Arundina yang ditemukan di Sumatera Barat dengan tiga varian warna bunga yaitu putih, pink dan ungu (Syamsuardi, Tamin dan Okada, 1995). Adanya bermacam-macam varian warna ini mengindikasikan bahwa ada diferensiasi morfologi (terutama warna bunga) antar ketiga varian tersebut. Selanjutnya Rukmini (1997) telah mengungkapkan bahwa ketiga varian Arundina graminifolia yang tumbuh di Ladang Padi mempunyai pola perbungaan dan sistem polinasi yang berbeda, pada tahap perkembangan (mulai dari kuncup kecil - bunga layu) bunga putih mencapai panjang maksimum lebih cepat diikuti oleh bunga pink dan ungu. Kemudian juga ditemukan adanya isolasi reproduksi antara varian bunga putih dengan variang bunga pink dan ungu. Berdasarkan hal ini, kemungkinan varian bunga putih merupakan takson yang berbeda dengan varian bunga pink dan ungu. Oleh karena itu perlu dilakukan pengamatan ultrastruktur morfologi polen untuk dapat mendukung diferensiasi morfologi antara ketiga varian tersebut.

Perbandingan palinologi untuk analisis kekerabatan fenetik telah banyak dilakukan dengan mengamati variasi mikro morfologi seperti bentuk, tipe dan apertura polen serta ornamentasi eksin. Ornamen tersebut biasanya berupa spina atau duri dan dapat pula berupa batang kecil dengan ujung berupa bola. Ornamen pada eksin dapat dijadikan sebagai ciri khas polen dari suatu spesies (Radford, 1986). Sementara apertura merupakan suatu area tipis pada eksin yang langsung atau tidak langsung berhubungan dengan pertunasan. Moore, Web and Collinson (1991) menyatakan bahwa apertura merupakan salah satu sifat penting yang dapat digunakan untuk penamaan jenis.

\section{Metodologi}

Penelitian dilakukan dengan metode survey di beberapa lokasi di Sumatera Barat, yaitu di Ladang Padi, Air Sirah, Lubuk Selasih, Alahan Panjang, Batang Palupuh dan Matur 
Kab. Agam. Penentuan lokasi pengambilan sampel berdasarkan informasi tulisan dan lisan. Pengamatan karakteristik morfologi dan ultrstruktur butir polen dilakukan dengan menggunakan Scanning Electron Microscope JEOL JSM 5310 LV di Laboratorium Widya Satwaloka LIPI Cibinong, Bogor.

Sampel polen diperoleh dari koleksi bunga yang belum mengalami anthesis dan dimasukkan ke dalam larutan FAA. Di laboratorium polen difiksasi dalam buffer glutaraldehid $2,5 \%$ pada suhu $4^{\circ} \mathrm{C}$ selama 1-2 jam, lalu dibilas dengan buffer dingin 3 kali masing-masing 15 menit. Kemudian difiksasi lanjut dalam osmium tetraoksida berbuffer dingin selama 3-12 jam. Setelah itu dibilas dengan akuades dingin 3 kali masing-masing selama 15 menit. Dilakukan dehidrasi bertingkat dalam aseton $25 \%$, $50 \%, 75 \%$ dan $100 \%$ masing-masing selama 20 menit. Pada aseton $100 \%$ diulang 3 kali, tiap kali selama 10 menit. Kemudian dimasukkan dalam larutan substitusi aseton dan amil asetat dengan perbandingan 3:1 selama 15 menit $1: 1$ selama 15 menit dan 1:3 selama 15 menit. Pengeringan dengan Critical Point Drying dengan CO2 cair pada titik kritis selama 15 menit. Lalu sampel dipasang pada holder dengan melekatkan pada selotip dua sisi rekat yang diatur dengan menjepitkan holder pada penjepit sehingga sampel menghadap ke dalam. Kemudian dilakukan pelapisan dengan emas murni dengan alat ion sputteting JEOL IB2 selama 15 menit. Setelah selesai holder diambil lalu dipasang pada mikroskop electron pemindai JEOL JSM 5310 LV dan diambil gambar polen yang paling baik kemudian dipotret untuk diidentifikasi (Wang, 2003, cit Susanti, 2009).

Ukuran morfologi polen dihitung berdasarkan panjang sumbu polar dan sumbu ekuatorial dalam skala mikrometer. Penentuan bentuk polen dapat diketahui dengan membandingkan antara panjang sumbu polar dengan sumbu ekuatorial, hal ini berdasarkan pada tulisan Kapp (1960) dan Erdtman (1952). Ukuran polen ditentukan berdasarkan tulisan Halbritter et,al. (2009).

\section{Hasil dan Pembahasan}

Bentuk polen, hasil pengukuran sumbu polar (P) dan sumbu ekuatorial (E) serta ukuran polen ditampilkan pada Tabel 1 .

Tabel 1. Bentuk dan ukuran polen pada tiga varian Arundina graminifolia

\begin{tabular}{cccccc}
\hline Varian & $\begin{array}{c}\text { Bentuk } \\
\text { Polen }\end{array}$ & $\begin{array}{c}\text { Rata- } \\
\text { rata } \\
\text { PSP } \\
(\mu \mathrm{m})\end{array}$ & $\begin{array}{c}\text { Rata-rata } \\
\text { PSE } \\
(\mu \mathrm{m})\end{array}$ & P/E \pm s.d & $\begin{array}{c}\text { Ukuran } \\
\text { Polen }\end{array}$ \\
\hline Putih & $\begin{array}{c}\text { Oblat } \\
\text { sferoidal } \\
\text { Prolat } \\
\text { Pink } \\
\text { sferoidal } \\
\text { Prolat }\end{array}$ & 26,76 & 27,6 & $0,97 \pm 0,02$ & $\begin{array}{c}\text { Kecil - } \\
\text { sedang } \\
\text { Ungu }\end{array}$ \\
$\begin{array}{c}\text { Pecil - } \\
\text { sferoidal } \\
\text { sedang } \\
\text { Kecil - } \\
\text { sedang }\end{array}$ \\
\hline Ket: PSP: panjang sumbu polar \\
PSE: panjang sumbu ekuatorial \\
P/E: rasio panjang sumbu polar/ sumbu ekuatorial
\end{tabular}

Tabel 1 memperlihatkan adanya perbedaan bentuk polen pada Arundina graminifolia varian putih dengan varian pink dan ungu. Pada varian putih didapat rata-rata panjang sumbu polar $26,76 \mu \mathrm{m}$ dan rata-rata panjang sumbu ekuatorial 27,6 $\mu \mathrm{m}$, sedangkan rasio panjang sumbu polar dengan panjang sumbu ekuatorial $0,97 \pm 0,02$, polennya berbentuk oblat sferoidal dengan ukuran kecil-sedang. Pada varian pink didapat rata-rata panjang sumbu polar $27,88 \mu \mathrm{m}$, rata-rata panjang sumbu ekuatorial $25,57 \mu \mathrm{m}$, rasio panjang sumbu polar dengan panjang sumbu ekuatorial $1,09 \pm 0,03 \mu \mathrm{m}$ dan polennya berbentuk prolat sferoidal dengan ukuran kecilsedang. Dan varian ungu didapat rata-rata panjang sumbu polar $30,53 \mu \mathrm{m}$, rata-rata panjang sumbu ekuatorial 30,1 $\mu \mathrm{m}$, rasio panjang sumbu polar dengan panjang sumbu ekuatorial $1,02 \pm 0,02 \mu \mathrm{m}$ dan polennya berbentuk prolat sferoidal dengan ukuran kecil-sedang.

Ornamentasi eksin pada ketiga varian ditemukan adanya reticulum. Pada penampakan polar ditemukan adanya celah meridional yang bertemu dan bersatu pada kutub (kolpus). Jumlah celah pada ketiga varian sama yaitu tetra kolpat (empat celah) dan tri kolpat (tiga celah) (Gambar 1). Berdasarkan ornamentasi eksin dan tipe apertura, ketiga varian tidak dapat dibedakan. Moore, Web, Collinson (1991) berpendapat bahwa apertura merupakan 
salah satu sifat penting yang dapat digunakan untuk identifikasi tanaman. Syamsuardi, Okada, Ogawa (2002) dan Syamsuardi, Mansyurdin, T. Maideliza, Febrinayani (2010) juga telah menggunakan polen untuk mengevaluasi taksa.

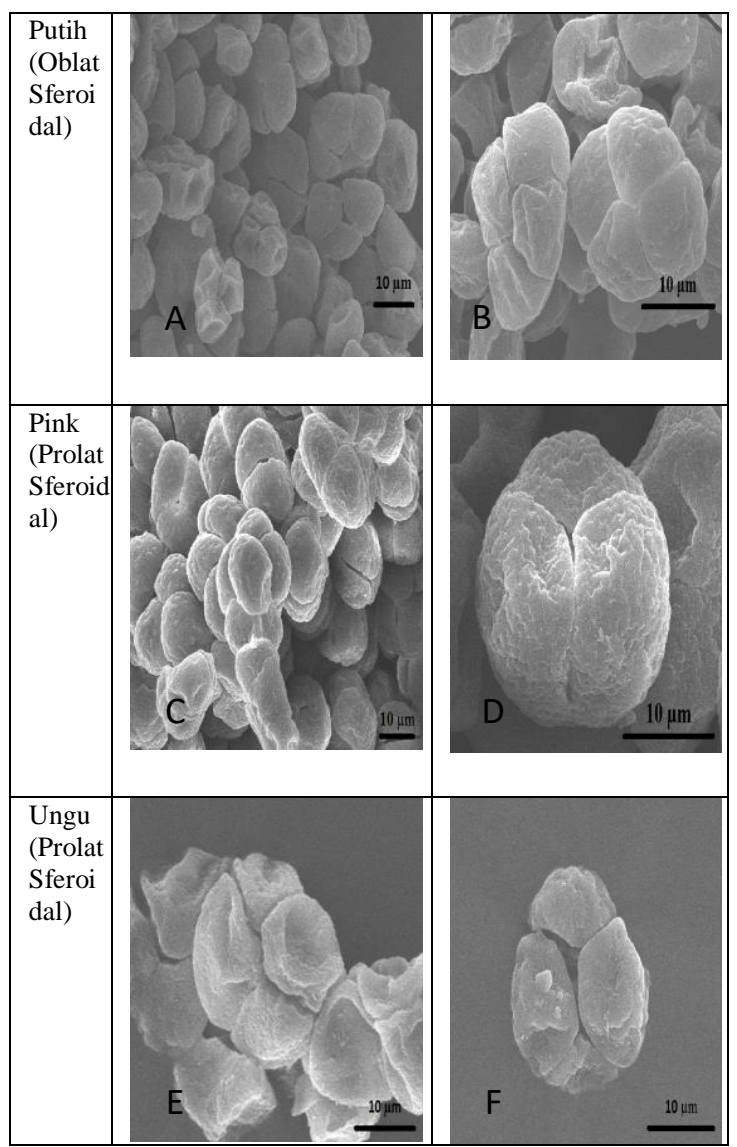

Gambar 1. Bentuk (tipe) Polen Tiga Varian Arundina graminifolia dengan menggunakan SEM

\section{Kesimpulan}

Berdasarkan pengamatan yang dilakukan terhadap Arundina graminifolia, ditemukan bahwa bentuk polen varian putih berbeda dengan varian pink dan ungu, dimana bentuk oblat sferoidal ditemukan pada varian putih dan prolat sferoidal pada varian pink dan ungu. Sementara itu, pada ketiga varian Arundina graminifolia ditemukan ornamentasi eksin berupa reticulum dan terdapat kolpus dengan tipe yang sama yaitu tri kolpat dan tetra kolpat.

Penggunaan SEM dalam melihat ultrastruktur pollinia pada anggrek telah dapat memberikan pemahaman yang lebih baik tetntang morfologi pollinia, sehingga dapat memperkuat kedudukan suatu jenis anggrek dalam suatu takson. Seperti halnya penelitian Sulistyono, Purbaningsih dan Pujoarianto (2000) yang menemukan bahwa pada subtribus Aeridinae, species Kingidium deliciosum cenderung keluar dari kelompok Phalaeonopsis dan Ascocentrum serta berdiri sendiri sebagai genus Kingidium, karena memiliki jumlah pollinia empat dengan ukuran tidak sama besar dan tidak dijumpai adanya porus ataupun lekukan, seperti halnya ditemukan pada species lain yang berada dibawah subtribus Aeridinae.

\section{Ucapan Terimakasih}

Pada kesempatan ini penulis menyampaikan ucapan terima kasih yang sebesar-besarnya kepada Dr. Nurainas, MSi, Dr. Ardinis Arbain, Dr. Erizal Mukhtar M.Sc, dan Dr. Chairul M.S atas kritik dan sumbangsih saran yang membangun, Kepala Laboratorium Widya Satwaloka LIPI Cibinong Bogor atas fasilitas yang disediakan, rekan-rekan di Herbarium Universitas Andalas dan KCA-LH Rafflesia FMIPA Unand, tim lapangan, serta semua pihak yang telah memberikan kontribusi dalam penelitian dan tulisan ini.

\section{Daftar Pustaka}

Erdtman, G. 1952. Pollen Morphology and Plant Taxonomy Angiosperms. Almquist \& Wik-sell, Stockholm The Chronica Botanica Co. Waltham, Mass.

Febrinayani. 2011. Klasifikasi Numerik Genus Etlingera (Zingiberaceae) di Sumatera Barat. Tesis Program Pasca Sarjana. Universitas Andalas. Padang.

Halbritter, H., Hesse, M., Zetter, R., Buchner, R., Frosch-Radivo, A. and Ulrich, S. 2009. Pollen Terminology an Illustrated Handbook. Springer Wien. Njnew York. 
Kapp, R.O. 1969. How To Know Pollen And Spores. W.M.C. Brown Company. Dubuque Keng. H. 1978. Orders and Families of Malaya Seed Plant. Singapore University Press. Singapore.

Moore, P.D., J.A. Webb and M.E. Collinson. 1991. Pollen Analysis. Blackwell Scientific Publication. Oxford.

Radford, A.E. 1986. Fundamentals of Plant Systematics. Harper and Row Published. New York.

Rukmini. 1997. Perbungaan Dan Sistem Polinasi Anggrek Bambu (Arundina) Yang Terdapat Di Ladang Padi Sumatera Barat. Skripsi Sarjana Biologi. FMIPA Universitas Andalas. Padang.

Sulistyono, S. Purbaningsih dan A. Pujoarianto. 2000. Ultrastruktur Pollinia Pada Sepuluh Species Anggrek Pada Subtribus Aeridinae (Orchidaceae). Yogyakarta: Jurnal Mikroskopi dan Mikroanalisis. Vol. 3, No. 1: 21-24.
Susanti, T. 2009. Klasifikasi Numerik Genus Globba (Zingiberaceae) Di Sumatera Barat. Thesis Pasca Sarjana. Universitas Andalas. Padang.

Syamsuardi, R. Tamin dan H. Okada. 1995. Numerical Taxonomy Analysis on Variation of Arundina graminifolia (Orchidacee) at Ladang Padi. West Sumatera.

Syamsuardi, H. Okada dan M. Ogawa. 2002. A New Variety of Ranunculus japonicus (Ranunculaceae) and Its Genetic Realtionship to the Related Species of Sect. Acris in Japan. Acta Phytotaxonomica et Geobotanica. 53 (2): 121-132.

Syamsuardi, Mansyurdin, Tesri Maideliza dan Febrinayani. 2010. Variasi Morfologi Dan Ultrastruktur Polen Genus Etlingera (Zingiberaceae) Di Sumatera Barat. Jurusan Biologi FMIPA Universitas Andalas. Padang. 